МРНТИ 68.47.75

УДК 631.1

https://doi.org/10.51579/1563-2415.2021-1.15

\title{
METHODS OF RISK MINIMIZATION IN THE DEVELOPMENT OF AGRO-INDUSTRIAL ENTREPRENEURSHIP
}

*Ye. Saparov, G. Tuleshova, A. Saparova

«Zhetysu University n.a. I. Zhansugurov» NP JSC. Taldykorgan, Kazakhstan

e-mail:kingbara@mail.ru

Annotation. In the conditions of modern market relations, the activity of any industrial enterprise is impossible without risks. It is almost impossible to avoid risk in production activities, so the main task is to assess the possible risk and develop measures to prevent it. Agro-industrial production is most affected by factors that lead to risks. Agroindustrial production is the basis of the country's life, and is a producer and supplier of vital products. This article examines the impact of risks on the results of agricultural production, identifies the stages of risk management, as well as various approaches to risk classification, analyzes the main causes and consequences of risks in agricultural enterprises.

Key words: risk, risk management, agro-industrial complex (AIC), market economy, agro-industrial production.

Statement of the problem in general form and its connection with important scientific and practical tasks. Agricultural production is one of the riskiest types of business activity. This is determined by an innumerable number of factors, including: the dependence of production on natural and climatic conditions and weather; seasonality of production and a long period of capital turnover; difficulties in changing the range of activities, the introduction of new equipment and technologies. Therefore, in the process of finding ways to overcome the existing risks in the agricultural business and achieve sustainable development by agricultural enterprises, first of all, the agricultural producer must determine the risks that most affect the effectiveness of its activities and what tools can be used to minimize this impact in order to achieve sustainable development.

Main provisions of the article.

Tools that agricultural producers can use: the use of effective technologies, rational use of mineral fertilizers and means of plant protection, grounded for equipment, diversification of production, training of highly qualified specialists, the creation of marketing schemes, vertically oriented enterprises. However, an economic entity can use these instruments if its financial condition is stable and there is free access to credit resources.

Tools for attracting and using which the agricultural producer should turn to the private sector (bank, insurance company, credit union, leasing company).

Macroeconomic methods based on the government's regulatory policy in the agricultural market and state programs to support this sector of the economy.

In the process of strategic planning, research and risk management in agricultural production, it is advisable to use the method of SWOT analysis, the main advantage of which is the possibility of simultaneous research of the external and internal environment of the object.

One of the defining problems in agriculture remains the lack of complete and comprehensive economic information on each of these tools. For this reason, the application of simple methods of economic analysis seems impossible, especially from a practical point of view. The use of SWOT analysis techniques in the study of tools to minimize the impact of agricultural risks opens up prospects, first, for the effective use of their strengths in achieving sustainable agricultural development; secondly, to identify additional opportunities for a positive impact on the environment and to minimize the impact of possible risks.

Introduction. The agro-industrial complex of Kazakhstan is a vivid example of clustering the economy. To understand the risks that farmers in Kazakhstan may face, it is necessary to define the main criteria for clustering agriculture. Analysis of the global economic practice shows that the most cost-effective, competitive and promising direction of development of business is industrial cooperation, which involves small, medium and large businesses, which ultimately leads to the establishment of industrial units called clusters [1].

M. Porter identifies the most important features of the category: "a cluster is a group of geographically neighbouring interconnected companies and related organizations operating in a certain area, characterized by common activities and complementary to each other." These enterprises form the production chain for specific product (Table.1).

M. Porter argues that clusters can influence competition in 3 ways:

- they can increase the performance of the companies in the cluster;

- they can stimulate innovations [2];

- they can stimulate the development of new business areas.

To formulate a more precise definition of the concept of "agricultural risk", it is necessary to consider the positions of some authors on this issue. 
Table 1

Influence of clusters on competitiveness (M. Porter).

\begin{tabular}{|c|c|c|}
\hline $\begin{array}{l}\text { The direction of the impact of clusters on } \\
\text { competitiveness }\end{array}$ & & \\
\hline $\begin{array}{l}\text { Increased productivity of firms and indus- } \\
\text { tries }\end{array}$ & $\begin{array}{l}\text { Create opportunities for } \\
\text { innovation and industri- } \\
\text { al growth }\end{array}$ & $\begin{array}{l}\text { Promoting and facilitating the formation of } \\
\text { a new business that supports innovation } \\
\text { and expansion of the cluster }\end{array}$ \\
\hline $\begin{array}{l}\text { 1. Competition creates more efficient spe- } \\
\text { cialization within a cluster }\end{array}$ & $\begin{array}{l}\text { 1. The creation of chan- } \\
\text { nels for effective coop- } \\
\text { eration of potentially } \\
\text { new resources for inno- } \\
\text { vation }\end{array}$ & $\begin{array}{l}\text { 1. The best competence in handling ven- } \\
\text { ture capital and the development of fast- } \\
\text { growing companies }\end{array}$ \\
\hline $\begin{array}{l}\text { 2. The emergence of more demanding } \\
\text { consumers. A higher level of specializa- } \\
\text { tion in the production process creates op- } \\
\text { portunities to take advantage of economies } \\
\text { of scale, for example, joint purchase of } \\
\text { raw materials, or conducting joint market- } \\
\text { ing research }\end{array}$ & $\begin{array}{l}\text { 2. Early detection and } \\
\text { forecasting technology } \\
\text { trends }\end{array}$ & $\begin{array}{l}\text { 2. Communication and links within the } \\
\text { cluster contribute to the emergence of } \\
\text { complementary skills, technologies and } \\
\text { subsidies. The ability of companies to at- } \\
\text { tract complementary skills allows you to } \\
\text { participate in larger transactions in which } \\
\text { individual companies are not competitive }\end{array}$ \\
\hline $\begin{array}{l}\text { 3. Access to technology, suppliers, skilled } \\
\text { labour, information, business services etc. }\end{array}$ & $\begin{array}{l}\text { 3. A favorable envi- } \\
\text { ronment for the emer- } \\
\text { gence of combinations } \\
\text { of previously existing } \\
\text { qualifications (abilities) }\end{array}$ & $\begin{array}{l}\text { 3. Support the emergence of new partici- } \\
\text { pants }\end{array}$ \\
\hline $\begin{array}{l}\text { 4. A high level of expertise to help im- } \\
\text { prove supply chain and also contributes to } \\
\text { the process of cooperation and learning } \\
\text { (improvement) in the cluster }\end{array}$ & $\begin{array}{l}\text { 4.Favorable conditions } \\
\text { for risk allocation }\end{array}$ & $\begin{array}{l}\text { 4. Strengthening social and other informal } \\
\text { links, leading to new ideas and business }\end{array}$ \\
\hline $\begin{array}{l}\text { 5. Clustered development can improve the } \\
\text { infrastructure of professional, financial, } \\
\text { and other services }\end{array}$ & $\begin{array}{l}\text { 5.Improved information } \\
\text { flows within the cluster }\end{array}$ & \\
\hline
\end{tabular}

Note: compiled by the authors.

Thus, under the agricultural risk O. N. Ostapenko understands "the negative deviation of actual result from planned activities (loss) due to the impact of negative factors of the climatic, financial and political - legal nature in the agricultural sphere" [3].

Yarovaya T. Yu. believes that " risk should be interpreted as a decrease or loss of income by a business entity due to the occurrence of adverse events that are probabilistic in nature." At the same time, the author does not single out the concept of agricultural risk separately.

In our opinion, agricultural risk should be understood as a danger, the probability of causing damage to agricultural producers by disrupting the functioning of the production process due to the influence of external and internal factors [4].

Thus, the concept of "agricultural risk" and "risk in agriculture" should be separated. So, if agricultural risk is understood as a risk associated with the influence of natural and climatic factors, i.e. one of the types of production risk, then the concept of "risks in agriculture" means various types of production risks, price and market risks, business and financial risks, etc.

Methodology. In the process of the study were used General methods of research: methods of analysis of financial statements: horizontal, vertical, ratio, comparison, and other.

To explore the agriculture environment and crisis management in Kazakhstan were used General scientific and special research methods:

- review of the regulatory framework;

- analytical method;

- economic-mathematical calculations.

The theoretical basis of the work is the fundamental works of domestic and foreign scientists in the field of economic theory, market relations and enterprise Economics. The study studied theories, concepts and approaches to the management of complex economic systems of agribusiness entities. The study is based on the economic laws and 
laws of the process of interaction of production systems. The study is based on the system analysis and synthesis of the processes of interaction of production processes in complex economic systems in an unstable environment. The paper investigates the materials of legislative, regulatory, instructive and methodological nature in the field of state regulation of economic and legislative relations of economic entities. As an empirical base we used statistical data obtained from official sources, published in domestic and foreign literature, information of operational and statistical reporting of economic entities.

Results. The method of minimizing risks in the agricultural sector includes: diversification of agricultural systems, its task is to determine the most profitable combinations of various types of activities; insurance of risks in the field of agriculture; forward contracts, which involve payment of goods at a price that is agreed in advance, i.e. before the delivery or production of goods. These measures cannot completely eliminate the risk in the activities of enterprises, but they can reduce the existing risks [5]. Currently, in many countries, risk management and problems in this area are brought to the state level. Summing up, it should be noted that agro-industrial production is the most unstable and unattractive industry for potential investors. Timely identification of risks, their analysis and competent management will allow agricultural enterprises to make the right management decision in time and avoid negative consequences [6].

Methods for reducing risks in the agricultural sector at the macro level include: insurance, whose main objective is to compensate producers of property losses of crops, caused by the influence of climatic risks and improve the financial situation of farmers and provide better access to credit; limitation - setting a limit, i.e. the limit of the amounts of costs, sales, credit, etc.; hedging is to avoid price and inflation risks in the implementation of enterprise transactions on the commodity or stock exchanges.

The main methods of reducing the risks of the agricultural sector at the micro level are: increasing the level of capitalization, reducing weather risks, diversification and specialization [7].

Thus, economic methods of risk management have significant limitations in the formation and implementation of the development strategy of the agribusiness organization. They should be supplemented by organizational and socio-psychological methods of risk management.

Organizational risk management methods are based on the use of organizational measures (administrative and logistics solutions) to ensure risk reduction.

Organizational risk management methods include the following types:

1) organizational and stabilizing, which are aimed at coordinating risk management activities. They include:

$\square$ distribution of risk management functions among the structural divisions of the agricultural enterprise, as well as the formation of structural divisions for risk analysis and management;

$\square$ setting standards, standards and limits that ensure risk reduction in the process of agricultural enterprise development;

$\square$ formation of a subsystem of information support for decision-making on risk management when planning the development of an agricultural enterprise;

$\square$ determination of control procedures for management decisions made in the process of agricultural enterprise development;

2) distributive - aimed at prompt adoption of corrective decisions in the process of risk management during planning. Economics and management of agricultural enterprise development in order to improve its efficiency, fill in the shortcomings of strategic risk management measures [8];

3) disciplinary-aimed at reducing the risks in planning the development of an agricultural enterprise associated with limiting the freedom of choice of actions in the implementation of the strategy.

Socio-psychological methods of risk management are focused on a group of people involved in the process of forming and implementing the development strategy of an agribusiness enterprise, which has a certain freedom of choice, which is both an additional risk factor (due to the uncertainty of the results of decision-making), and a factor in reducing the possibility and severity of the consequences of risks by involving individual knowledge in the risk management process [9].

The effective use of socio-psychological methods of risk management largely depends on the conditions of their use: management style, competence of managers of the agro-industrial complex, etc.

Thus, the effective use of risk reduction methods in agro-industrial production will increase the efficiency of the agro-industrial complex.

Conclusions. Risk should be interpreted as a decrease or loss of income by a business entity due to the occurrence of adverse events that are probabilistic in nature.

According to research, the risks of the agricultural sector are closely interrelated, and therefore it is quite difficult to distinguish between their types.All of the above types of risks affect the company's profit and constitute income risk. Thus, there is no doubt that under conditions of incomplete market openness, price risk and yield risk are in the position of substitution. In other words, one of the risks is partially compensated at the expense of the other. When the market is more open, the degree of substitution decreases. There is also a close relationship between institutional 
and financial risks. This is due to the fact that with the low capitalization of the agricultural sector, there is practically no collateral for a loan. This increases the risk of lending, prompting lenders to raise interest rates.

Risk management uses methods of preserving risk and compensating for damage, reducing and eliminating risk, transferring responsibility for risk through insurance, financial guarantees and guarantees, making provisions on risk in contracts and contracts, etc.

Thus, having analyzed the concept and main types of risks in agriculture, it is worth noting that, like subjects of other industries, agricultural producers are subject to various types of production and market risks. At the moment, not only agricultural producers, but also the state should have a direct impact on reducing the level of agricultural risks, which will be an effective step in attracting private investment in the industry.

\section{List of references:}

1 Кодекс Республики Казахстан о налогах и других обязательных платежах в бюджет (Налоговый кодекс) от 1 января 2018 года № 209 - II с изменениями от 18 марта 2018 года № 537, № 107 - III.

2 Кожухарь В. М. Практикум по экономической оценке инвестиций: учебное пособие. Издательскоторговая корпорация "Дашков и Ко". - 2015. - с. 146-148.

3 Стоянова Е. С. Финансовый менеджмент. Учебник для вузов, Издательство «Видение». - 2017. - с. $421-425$.

4 Bota D. Baitarakova, Rayhan K. Turysbekova, Farrukh A. Gajiyev, Zhuldyz K. Subebaeva, Makpal T. Syrlybaeva, Barkhudar Sh. Gussenov. (2018). Using the principles of project financing as an effective instrument of management of transport infrastructure (Using elements of public - private partnerships). Espacios. Vol. 39 (Number 19). Page 42 - 46.

5 Осмоловский В., Кравченко Л. И., Русак Н. А. и др. Теория анализа хозяйственной деятельности, учебник. Новое издание. - 2016. - с. 149-156.

6 Статистика за 2008-2020 годы (по периодам). Комитет по статистике http://www.stat.gov.kz/ 2020.

7 Багиева М. Н. Концептуальные основы анализа и оценки рисков предприятия: Учебное пособие по курсу "Управление рисками", М-во образования РФ, Санкт-Петербург. Университет экономики и финансов. СПб.: Изд-во С.-Петерб. государственного экономико-финансового университета. - 2013. - c. 48-51.

8 Большов В. А. Управление рисками: учебное пособие Министерство образования Российской Федерации, Казань. финансово-Экономический. - 2012. - с.89-110.

9 Gussenov B.Sh. (2017). Regional aspects of implementation of foreign economic activities of Almaty region. Scientific achievements and discoveries of modern youth, collection of articles of the winners of the International scientific and practical conference: in 2 parts. P. 551-553.

List of references(транслитерация):

1 Kodeks Respubliki Kazakhstan o nalogakh i drugikh obyazatelnykh platezhakh v byudzhet (Code of the Republic of Kazakhstan on Taxes and Other Mandatory payments to the Budget) ot 1 yanvarya 2018 goda No. 209 II s izmeneniyami ot 18 marta 2018 goda No. 537, No. 107 - III.

2 Kozhukhar V. M. Praktikum po ekonomicheskoi otsenke investitsii (Workshop on the economic assessment of investments): uchebnoe posobie. Izdatelsko-torgovaya korporatsiya "Dashkov i Ko", 2015, pp. 146 -148.

3 Stoyanova E. S. Finansovyi menedzhment (Financial management), uchebnik dlya vuzov, Izdatelstvo «Videnie», 2017, pp. 421-425.

4 Baitarakova B. D., Turysbekova R. K., Gajiyev F.A., Subebaeva Zh.K., Syrlybaeva M.T., Gussenov B.Sh.. Using the principles of project financing as an effective instrument of management of transport infrastructure (Using elements of public - private partnerships), Espacios, 2018, Vol. 39 (No. 19), pp.42 - 46.

5 Osmolovskii V., Kravchenko L. I., Rusak N. A. i dr. Teoriya analiza khozyaistvennoi deyatelnosti (The theory of analysis of economic activity), uchebnik, Novoe izdanie, 2016, pp. 149-156.

6 Statistika za 2008-2020 gody (po periodam). Komitet po statistike http://www.stat.gov.kz/2020.

7 Bagieva M. N. Kontseptualnye osnovy analiza i otsenki riskov predpriyatiya (Conceptual framework for enterprise risk analysis and assessment): Uchebnoe posobie po kursu "Upravlenie riskami", M-vo obrazovaniya RF, Sankt-Peterburg. Universitet ekonomiki i finansov, Izd-vo S.-Peterb, gosudarstvennogo ekonomiko-finansovogo universiteta. 2013, pp. 48-51.

8 Bolshov V. A. Upravlenie riskami (Risk management): uchebnoe posobie Ministerstvo obrazovaniya Rossiiskoi Federatsii, Kazan, Finansovo-ekonomicheskii, 2012, pp.89-110.

9 Gussenov B.Sh. (2017). Regional aspects of implementation of foreign economic activities of Almaty region. Scientific achievements and discoveries of modern youth, collection of articles of the winners of the International scientific and practical conference: in 2 parts. P. 551-553. 


\title{
АГРОӨНЕРКӘСІПТІК КӘСІПКЕРЛІКТІ ДАМЫТУДАҒЫ ТӘУЕКЕЛДЕРДІ АЗАЙТУ ӘДІСТЕРІ
}

\author{
"Е. Сапаров, Г.Тулешова, А.Сапарова
}

«I. Жансүсіров атындагы Жетісу университеті» КЕ АҚ, Талдықорган, Қазақстан

e-mail:king_bara@mail.ru

Түйін. Қазіргі нарықтық қатынастар жавдайында кез-келген өндірістік кәсіпорындардың қызметі тәуекелсіз мүмкін емес. Өндірістік қызметте құуіп-қатерді болдырмау іс жүзінде мүмкін емес, сондықтан негізгі міндет ықтимал қауіпті бавалау және оның алдын-алу шараларын әзірлеу болып табылады. Агроөнеркәсіптік өндіріс тәуекелдердің пайда болуына әкелетін факторлардың әсеріне көбірек ұшырайды. Агроөнеркәсіптік өндіріс ел өмірінің негізін құрайды және өмірлік манызды өнімдерді өндіруші және жеткізуші болып табылады. Бұл мақалада тәуекелдердін ауыл шаруашылывы өндірісінін нәтиюелеріне әсері қарастырылван, тәуекелдерді басқару кезендері, сондай-ақ тәуекелдерді жіктеудің әртүрлі тәсілдері көрсетілген, АӨК кәсіпорындарында тәуекелдердің пайда болуының негізгі себептері мен салдары талдандан.

Түйін сөздер: тәуекел, тәуекелдерді басқару, Агроөнеркәсіптік кешен (АӨК), нарықтық экономика, агроөнеркасіптік өндіріс.

\section{МЕТОДЫ МИНИМИЗАЦИИ РИСКОВ В РАЗВИТИИ АГРОПРОМЫШЛЕННОГО ПРЕДПРИНИМАТЕЛЬСТВА \\ "Е. Сапаров, Г. Тулешова, А. Сапарова \\ НАО «Жетысуский университет им.И. Жансугурова», Талдыкорган, Казахстан *e-mail:king bara@mail.ru}

Резюме. В условиях современных рыночных отночений, деятельность любого производственного предприятий невозможна без рисков. Избежать риска в производственной деятельности практически невозможно, поэтому основной задачей является оченка возможного риска и разработка мероприятий по его предотвращению. Агропромышленное производство наиболее подвержено влиянию факторов, приводящих к возникновению рисков. Агропромышленное производство представляет собой основу жизнедеятельности страны, и является производителем и поставщиком жизненно необходимой продукции. В данной статье рассмотрено влияние рисков на результаты сельскохозяйственного производства, обозначены этапы управления рисками, а также различные подходы к классификачии рисков, проанализированы основные причины и последствия возникновения рисков на предприятиях АПК.

Ключевые слова: риск, управление рисками, агропромышленный комплекс (АПК), рыночная экономи$\kappa$, агропромышленное производство.

\section{IRSTI 06.39.31}

UDC 332.02

https://doi.org/10.51579/1563-2415.2021-1.16

\section{REGIONAL ECONOMIC SYSTEM AS AN INSTITUTION IN THE NATIONAL ECONOMY}

A. A. Sadykbekova ${ }^{* 1}$, T.A. Aydarov ${ }^{2}, A$. A. Meldebekova $^{3}$, A.R. Shalbayeva ${ }^{4}$

${ }^{1,4}$ Shymkent University, Shymkent, Kazakhstan

${ }^{2}$ NJC South Kazakhstan state university named after M. Auezov, Shymkent, Kazakhstan

${ }^{3}$ KazNPU named after Abai, Almaty, Kazakhstan e-mail: saijarkyn@mail.ru

Annotation. The study is devoted to the issues of the regional system, the effective and sustainable development of which is of particular importance in the vast space of the national economy of Kazakhstan.

Originality of the research. When considering the transformation of economic systems, due attention is not always paid to the interconnection and complementarity of the processes of forming economic relations and developing institutions. Institutional, socio-cultural, and post-industrial characteristics are very difficult to penetrate into the existing overly economized models of economic transformation. The issues of adaptation of economic development trends in highly developed countries to the national, socio-cultural conditions of post-socialist States undergoing a systemic transformation are relatively poorly developed.

The results of the research consist in a conceptual analysis and theoretical definition of the transformation of economic systems in the context of globalization processes, taking into account current trends in the development of the national economy.

Keywords: regional economy, regional system, system quality, globalization, development processes. 